\title{
Vaccination trials against 'red plague' in eels
}

\author{
G. Tiecco ${ }^{1}$, C. Sebastio ${ }^{1}$, E. Francioso ${ }^{1}$, G. Tantillo $^{1}$, L. Corbari ${ }^{2}$ \\ ${ }^{1}$ Istituto Ispezione degli Alimenti, Facoltà di Medicina Veterinaria, Università degli Studi di Bari, CP 7, I-70010 Valenzano, \\ Italy \\ ${ }^{2}$ Ittica Ugento, S.p.A. Torre Mozza, I-73059 Ugento-Lecce, Italy
}

\begin{abstract}
From killed cultures of Vibrio anguillarum and Aeromonas hydrophila, 4 vaccines were obtained: a formalin- and an ampicillin-inactivated preparation of each culture. Vaccination of eels Anguilla anguilla was performed by intramuscular injection and by immersion. Intramuscular vaccination with the $V$. anguillarum and $A$. hydrophila vaccines prepared by either method of inactivation induced statistically significant protection in eels experimentally challenged with the corresponding pathogen. Using immersion vaccination the A. hydrophila vaccines induced a statistically significant degree of protection but the $V$. anguillarum vaccines did not.
\end{abstract}

\section{INTRODUCTION}

Red plague is a disease that frequently occurs in eels farmed in brackish waters. The acute form of the disease is favoured by high water temperatures (Groberg et al. 1978, Cognetti et al. 1980. Groberg et al. 1983). The aetiological agents commonly isolated are Vibrio anguillarum and Aeromonas hydrophila. They are normally present in brackish water (Cognetti et al. 1980, Ghittino 1985) and when eels are stressed by increasing water temperatures, they can cause a high mortality rate and result in considerable economic loss (Rucker 1959, Cognetti et al. 1980, Ghittino 1985).

Many workers have attempted vaccination against red plague and other fish diseases using vaccines administered by injection, immersion or spraying (Garrison \& Gould 1976, Antipa \& Amend 1977, Gould 1977. Gould et al. 1978. Antipa et al. 1980, Giorgetti et al. 1981). The present authors have previously isolated both aetiological agents from a natural outbreak of this disease (Celano et al. 1985) and after some encouraging results with vaccination tests performed in the laboratory they now report on vaccination trials conducted on an eel farm (Ittica, Ugento, Lecce, Italy).

\section{MATERIALS AND METHODS}

Micro-organisms. Strains of Vibrio anguillarum and Aeromonas hydrophila used in these experiments were isolated during natural outbreaks of red plague
(Celano et al. 1985). They were cultured on Nutrient agar supplemented with $2 \% \mathrm{NaCl}$, even though only A. hydrophila subsequently proved to be halo-tolerant. The bacteria were maintained by (weekly) subculture on Nutrient agar which was supplemented with $2 \%$ $\mathrm{NaCl}$ in the case of $V$. anguillarum.

Preparation of vaccines. The 2 arganisms were cultured at $30^{\circ} \mathrm{C}$ for $48 \mathrm{~h}$ in aerated Nutrient broth with added $2 \% \mathrm{NaCl}$. Each broth culture was then divided into 2 portions to permit the preparation of the 2 different vaccines.

Formalin-inactivated vaccine: Formalin (final concentration $0.3 \%$ was added to a broth culture of each organism and then left at ambient temperature $\left(20^{\circ} \mathrm{C}\right)$ for $7 \mathrm{~d}$. After this period, sterility was demonstrated. The broth cultures were centrifuged at $3000 \times g$ for 20 min. The whole killed cells obtained were suspended in sterile distilled water and stored at $4{ }^{\circ} \mathrm{C}$ until used.

Ampicillin-inactivated vaccine: The second portion of each broth culture was used for the preparation of a vaccine inactivated with ampicillin. Ampicillin (final concentration $0.3 \%$ ) was added to each broth culture and the culture left at $30^{\circ} \mathrm{C}$ for $5 \mathrm{~d}$, at which time sterility was demonstrated. The cultures were centrifuged at $3000 \times g$ for $20 \mathrm{~min}$. The resulting sediment was suspended in sterile distilled water and stored at $4^{\circ} \mathrm{C}$ until used.

Experimental animals. For the experiment, 500 eels Anguilla anguilla weighing 80 to $90 \mathrm{~g}$ each were employed. The eels were kept in 100 l tanks with circulating water, and the water temperature was 
maintained at $20^{\circ} \mathrm{C}$. The eels were placed in the tanks $7 \mathrm{~d}$ before the start of the experiment to accustom them to the new conditions, and were not fed during the experiment.

The eels were subdivided into 10 groups of $50 \mathrm{sub}$ jects each and treated as follows:

Group 1: Each eel was injected intramuscularly with $0.5 \mathrm{ml}$ of formalin-inactivated vibrio vaccine.

Group 2: The eels were vaccinated by immersion for 5 min in a plastic tank containing $6 \mathrm{l}$ of water and 500 $\mathrm{ml}$ of formalin-inactivated vibrio vaccine.

Group 3: Each eel was injected intramuscularly with $0.5 \mathrm{ml}$ of ampicillin-inactivated vibrio vaccine.

Group 4: The eels were vaccinated by immersion for 5 min in a plastic tank containing $6 \mathrm{l}$ of water and 500 $\mathrm{ml}$ of ampicillin-inactivated vibrio vaccine.

Groups $6,7,8$ and 9 received the same treatment as Groups 1 to 4 except that the corresponding Aeromonas hydrophila vaccines were substituted for the vibrio vaccines.

Group 5 was used as the unvaccinated control for the groups treated with vibrio vaccines (Groups 1 to 4 ), and Group 10 was used as the control for the groups ( 6 to 9) treated with the Aeromonas hydrophila vaccines. The control groups (5 and 10) were not sham-treated in any way before challenge.

Twelve d after the vaccinations, all groups were challenged by intramuscular injection with $0.5 \mathrm{ml}$ of the appropriate broth culture (grown for 24 h at $30^{\circ} \mathrm{C}$ ) as follows: Groups 1 to 5 were challenged with the Vibrio anguillarum culture and Groups 6 to 10 were challenged with the Aeromonas hydrophila culture. The eels were observed for $30 \mathrm{~d}$ post-challenge. Every eel that died during the experiment was examined by culture for the presence of the challenge organism.

Evaluation of results. Statistical evaluation of the results was performed by the chi square test $\left(\chi^{2}\right)$ (Cavalli-Sforza 1977).

\section{RESULTS AND DISCUSSION}

During the period between the start of the experiment and the challenge, 24 eels died. Necropsy and bacteriological tests on these eels demonstrated that death was not due to red plague.

The resuits of the experiment are shown in Table 1. Necropsy performed on all of the eels that died after challenge demonstrated typical lesions of red plague and it was possible to reisolate the injected aetiological agent in pure culture.

Intramuscular vaccination performed either with the formalin- or the ampicillin-inactivated vibrio vaccine induced statistically significant protection. The ampicillin-inactivated vaccine gave slightly better protection, but the difference was not statistically significant.

Results with eels treated intramuscularly with the formalin-and ampicillin-inactivated Aeromonas hydrophila vaccines also showed a significant degree of protection. Again, the ampicillin-inactivated vaccine gave a slightly (statistically insignificant) better protection.

Table 1 Anguilla anguilla. Results of eel vaccination trials. Eels were vaccinated with inactivated whole cell vaccines administered by dipping them for $5 \mathrm{~min}$ in the vaccines or by intramuscular injection. Challenge was administered by intramuscular injection. Survival in each vaccinated group was compared with survival in the appropriate unvaccinated control group $_{i}+=$ significant protection

\begin{tabular}{|c|c|c|c|c|c|c|c|}
\hline $\begin{array}{l}\text { Group } \\
\text { no. }\end{array}$ & Vaccine & $\begin{array}{l}\text { Vaccination } \\
\text { method }\end{array}$ & $\begin{array}{l}\text { No. of eels } \\
\text { immunized and } \\
\text { challenged }\end{array}$ & $\begin{array}{c}\text { No. of eels } \\
\text { that died } \\
\text { on challenge }\end{array}$ & $\begin{array}{c}\text { No. of } \\
\text { surviving eels }\end{array}$ & $x^{2}$ & $\begin{array}{l}\text { Statistical } \\
\text { evaluation }\end{array}$ \\
\hline & \multicolumn{7}{|c|}{ Vibrio anguillarum } \\
\hline 1. & \multirow{2}{*}{$\begin{array}{l}\text { Formalin- } \\
\text { inactivated }\end{array}$} & Injection & 48 & 6 & 42 & 58.52 & + \\
\hline 2. & & Immersion & 49 & 41 & 8 & 1.37 & - \\
\hline 3. & \multirow{3}{*}{$\begin{array}{l}\text { Ampicillin- } \\
\text { inactivated }\end{array}$} & Injection & 50 & 2 & 48 & 76.28 & + \\
\hline 4. & & Immersion & 48 & 43 & 5 & 0.09 & - \\
\hline \multirow[t]{2}{*}{5.} & & $\begin{array}{l}\text { Unvaccinated } \\
\text { control group }\end{array}$ & 46 & 43 & 3 & & \\
\hline & \multicolumn{7}{|c|}{ Aeromonas hydrophila } \\
\hline 6. & \multirow{2}{*}{$\begin{array}{l}\text { Formalin- } \\
\text { inactivated }\end{array}$} & Injection & 49 & 8 & 41 & 59.83 & + \\
\hline 7 & & Immersion & 47 & 22 & 25 & 26.24 & + \\
\hline 8. & \multirow{3}{*}{$\begin{array}{l}\text { Amprcillin- } \\
\text { inactivated }\end{array}$} & Injection & 49 & 1. & 48 & 82.68 & + \\
\hline 9. & & Immersion & 41 & 14 & 27 & 36.22 & + \\
\hline 10 & & $\begin{array}{l}\text { Unvaccinated } \\
\text { control group }\end{array}$ & 49 & 47 & 2 & & \\
\hline
\end{tabular}


The immersion-administered vaccines obtained from Vibrio anguillarum did not induce significant protection. However, similar vaccines prepared from Aeromonas hydrophila induced protection that was statistically significant, even though the protection obtained was lower than that observed with the vaccines administered by intramuscular injection.

We are not able to explain why the immersionadministered vibrio vaccines failed to induce significant protection in the eels. More promising results might have been obtained if the vaccine had been prepared to contain the soluble extracellular products released by Vibrio anguillarum during its growth in broth culture. The vaccine tested contained only cellassociated immunogens.

The protection conferred by the more promising vaccines in this study must have been strong because an extremely severe challenge was used to assess vaccine efficacy. With both pathogens, the challenge dose administered was large enough to kill over $90 \%$ of the unvaccinated controls. This level of challenge was more severe than that normally occurring in eel farms.

The results indicate that further studies are needed if immersion vaccines effective against both forms of red plague disease are to be possible. Vaccination by immersion would be preferable to vaccination by intramuscular injection because it is easier to perform, is less traumatic for the eels, and would likely be less costly to administer.

\section{LITERATURE CITED}

Antipa, R., Amend, D. F. (1977). Immunization of Pacific salmon: comparison of intraperitoneal injection and hyperos- motic infiltration of $V$. anguillarum and $A$. salmonicida bacterins. J. Fish. Res. Bd Can. 34: 203-208

Antipa, R., Gould, R., Amend, D. F. (1980). V. anguillarum vaccination of sockeye salmon. (Oncorhynchus nerka) by direct immersion and hyperosmotic immersion. J. Fish Dis. 3: $161-165$

Cavalli-Sforza, L. (1977). Analisi statistica per medici e biologi e analisi statistica del dosaggio biologico. Boringhieri Editore, Torino, p. $59-63$

Celano, G., Francioso, E., Tantillo, G., Sebastio, C. (1985). Studio di un focolaio di 'Peste rossa' in un allevamento intensivo di anguille. Summa 2: 13-15

Cognetti, G., De Angelis, C. M. (1980). Anguille e anguillocoltura. Quaderni di biologia pura e applicata. Edricole, Bologna, p. 93

Garrison, R. L., Gould, R. W. (1976). Vibrio immunization studies. Federal Aid Progress Reports, Fisheries Research Section, Oregon Dept of Fish and Wildlife

Ghittiono, P. (1985). Tecnologia e patologia in acquacoltura. Vol. II. Emilio Bono, Torino, p. 96

Giorgetti, G., Tomasin, A. B., Ceschia, G. (1981). First Italian antivibriosis vaccination experiments of freshwater farmed rainbow trout. Develop. Biol. Standard 49: 455-459

Gould, R. W. (1977). Development of a new vaccine delivery system for immunizing fish and investigation of the protective antigens in $V$. anguillarum. Ph. D. thesis, Oregon State University, Oregon

Gould, R. W., O'Leary, P. J., Garrison, R. L., Rohovec, J. S., Fryer, J. L. (1978). Spray vaccination: a method for the immunization of fish. Fish Pathol. 13: 63-68

Groberg, W. J. Jr, McCoy, R. H., Pilcher, K. S., Fryer, J. L. (1978). Relation of water temperature to infections of coho salmon (Oncorhynchus kisutch), chinook salmon $(O$. tshawyscha), and steelhead trout (Salmo gairdneri) with Aeromonas salmonicida and A. hydrophila. J. Fish. Res. Bd Can. 35: 1-7

Groberg, W. J. Jr, Rohovec, J. S., Fryer, J. L., (1983). The effects of water temperature on infection and antibody formation induced by Vibrio anguillarum in juvenile coho salmon (Oncorhynchus kisutch). J. World Maricult. Soc. 14: $240-248$

Rucker, R. R. (1959). Vibrio infection among marine and freshwater fish. Progve Fish Cult. 21: 22-25 